Arab Univ. J. Agric. Sci., Ain Shams Univ., Cairo, Egypt 28(2), 521-528, 2020

Website: http://ajs.journals.ekb.eg

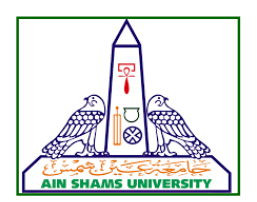

\title{
ASSESSMENT OF SPECTROSCOPIC AND MORPHOLOGICAL PROPERTIES OF SOME FRUIT CROPS UNDER THE INFLUENCE OF POLLUTION WITH HEAVY METALS USING REMOTE SENSING TECHNIQUES
}

\section{Amany F. El Wesemy ${ }^{1 *}$, Abdelghany ${ }^{2}$ N.A., Abou Hadid ${ }^{2}$ A.F. and Aboelgar ${ }^{1}$ M.A.I.}

1- National Authority for Remote Sensing and Space Sci., (NARSS), Cairo, Egypt

2- Horticulture Dept., Fac. of Agric., Ain Shams Univ., P.O. Box 68, Hadayek Shoubra 11241, Cairo, Egypt

*Corresponding author: amanysearch@ gmail.com

Received 3 May, 2020

Accepted 24 August, 2020

\section{ABSTRACT}

Dietary exposure to a variety of heavy metals, including $\mathrm{Ni}, \mathrm{Cd}, \mathrm{Cr}, \mathrm{Pb}, \mathrm{Zn}$, and $\mathrm{Hg}$, has been identified as a danger to human health through fruits and vegetables, contamination of heavy metals is known as a grave risk to our climate. The study aims to develop empirical models to predict the concentration of heavy metals ( $\mathrm{Ni}, \mathrm{Cd}, \mathrm{Cr}, \mathrm{Pb}, \mathrm{Zn}$, and $\mathrm{Hg}$ ) in the leaves of Citrus and Mango crops. The study was carried out in an observation site in Giza governorate that is cultivated by varied herbaceous and tree cover crops. This study area is suffering from severe pollution caused by near industrial district. The sample collected from deferent zones that are divided to six spatial zones and coded by from zone (2, 3, 4, 5, and 6). The distance between each Zone $10 \mathrm{Km}$ that extends from the north to south and covers $60 \%$ from the Agriculture area in the Giza governorate. The main inputs of the generated models were spectroscopic remotely sensed data and laboratory analytical measurements of heavy metals in crop leaves. ASD (Analytical Spectral Devices) field spectro-radiometer was used to calculate hyper-spectral vegetation indices. Modeled heavy metal concentrations were tested against laboratory analysis through two common statistical tests; the Correlation of determination $\left(R^{2}\right)$ and Root Mean square (RMSE) error between predicted modeled heavy metals. Results shown the correlation coefficient of the generated models, red and nearinfrared spectral bands demonstrated high precision and sufficiency for mango and citrus leaves to predict heavy metals. The models produced refer to specific regions with the same conditions. The overall results imply that hyper-spectral vegetation indices could be correlated with heavy metal content, while heavy metal content in plants may be influenced by many others. Remote sensing spectroscopy is a possible and promising technology to track the environmental pressures on agricultural vegetation. Additional ground remote sensing experiments are needed to assess the possibility of hyper-spectral reflectance spectroscopy in monitoring the stress of different types of metals on various plants.

Keywords: Heavy metal, Hyper-spectral Vegetation Indices, Empirical models, Giza governorate.

\section{INTRODUCTION}

Human activities, such as technological growth, mining, agriculture and traffic, release vast amounts of heavy metals into the surface and groundwater, the soil and ultimately into the biosphere. The accumulation of heavy metals in crops and the possibility of contamination of food via the soil root interface are a major concern. Heavy metals such as, Cd, Pb, and $\mathrm{Ni}$ is not essential for plant growth, they are readily absorbed and accumulated by toxic plants (Mussarat \& Bhatti; 2005; Qadir et al 1999; Bhatti 
\& Perveen, 2005). Heavy metals are natural elements that are not biologically degradable or damaged. Trace element to classify the elements that exist in small quantities in natural biological processes associated with the declining environmental quality resulted in a trace element (Asati et al 2016). For plants and animals, some heavy metals (Fe, Cu, and $\mathrm{Zn}$ ) are important (Wintz et al 2002). The presence varies in the medium and metals like $\mathrm{Cu}, \mathrm{Zn}, \mathrm{Fe}, \mathrm{Mn}, \mathrm{Mo}, \mathrm{Ni}$ and Co are important micronutrients (Reeves et al 2000). Its absorption over plant requirements contributes to toxic effects (Monnis et al 2000). On arable plants (Misra et al 1991) In the Nile delta, soil contamination by heavy metals is considered to be a major environmental issue. Most of which have toxic effects on plants and microorganisms in soil when allowable concentrations are exceeded (Mohamed et al 2016).

Multi- and hyperspectral images were checked for low-cost and rapid determination and quantitative analysis of soil properties essential to agriculture - water, nutrients, and organic matter content (Bonifazi et al 2004). Remote sensing presents rich spectral and typically spatially continuous information that can be used to determine more specific spectral properties of soil properties and mineralogy, which can be used to map and track pollution of soil in turn. Based on the spectral response of the sample, reflectance spectroscopy is also relatively lower in cost and faster than conventional wet chemical measurements.

Hyper-spectral spectrum imaging technique develops multiple line images across the field of light intensity, and this technology was used to detect apple firmness and soluble solids content (SSC- Lu, 2004 \& Mendoza et al 2011). However, spectral diffusion technology may be essentially inferior for SSC calculation as its sensing design aims to increase the scattering properties, leading to better firmness prediction but not in soluble solids content (Mendoza et al 2011). Hyper-spectral reflectance display technology, on the other hand, is another method of detecting the hyper-spectral imaging system, typically used for pear deterrence firmness and soluble solids content (Fan et al 2015), testing material properties, soluble solids content, and blueberries firmness (Hu et al 2015 \& Leiva et al 2013), forecasting soluble solids content and $\mathrm{pH}$ of strawberries (El-Masry et al 2007) and grapes (Baiano et al 2012). The current study aims to introduce a remotely sensed method to predict heavy metal contamination through statistical easily operated models.

\section{MATERIALS AND METHODS}

\section{Study area}

The area is located on the South of Giza Governorate on both sides of River Nile. It included different administrative areas in Al-Saff and Atfih. The boundary of the study area extends from north to south for a distance exceeding one hundred kilometers. The study area is close to the huge industrial community between $\left(29^{\circ} 47^{\prime} 55.22^{\prime \prime}\right.$ to $29^{\circ} 13^{\prime} 11.82^{\prime \prime}$ North) and from (31 ${ }^{\circ} 6{ }^{\prime} 32.00 ", 31^{\circ} 27^{\prime} 34.24 "$ East) with a total area of $(2288.76) \mathrm{Km}^{2}$. The depth of the study area is $64 \mathrm{~km}$ from Helwan industrial area while the width is $36 \mathrm{~km}$. That shown in Fig. (1).

\section{Field and Laboratory measurements}

Ninety-nine (99) leaves of mango and forty two (42) citrus sample leaves from six (6) spatial zones were collected for spectroscopic and laboratory measurements. The spatial zones and examples for field measurements are shown in Fig. (2). Spectral measurements for the samples were carried out using the ASD field spectroradiometer. Field observations and collection of the different samples were carried out in two days (23 and 24 March 2018).

Plant leaves were collected and used for laboratory analytical analysis for heavy metal using wet digestion procedure and the metal concentration in the digest was determined using atomic absorption spectroscopy.

\subsection{ASD spectroradiometer}

ASD (Field spectroradiometer), was used to collect spectra over the full range of the spectrum (visible and near-infrared) regions from (350 nm - 2500 $\mathrm{nm})$ for each trees sample at $(1,4 \mathrm{~nm}-2 \mathrm{~nm})$ intervals with a spectral wavelength of $(3 \mathrm{~nm}: 10 \mathrm{~nm})$. The ASD spectroradiometer measures the reflectance, transmission, radiance, and irradiance of an object. The recorded data are usually affected by the surrounding factors, such as sources of illumination, scanning time, atmospheric conditions, and field-of-view of the device. Spectral data were recorded concerning an external white reference panel. Then, three spectra for each sample were recorded, and the average values for the three spectral readings were calculated. Thus, one value was obtained to express the spectral characteristics of each measured leave. 


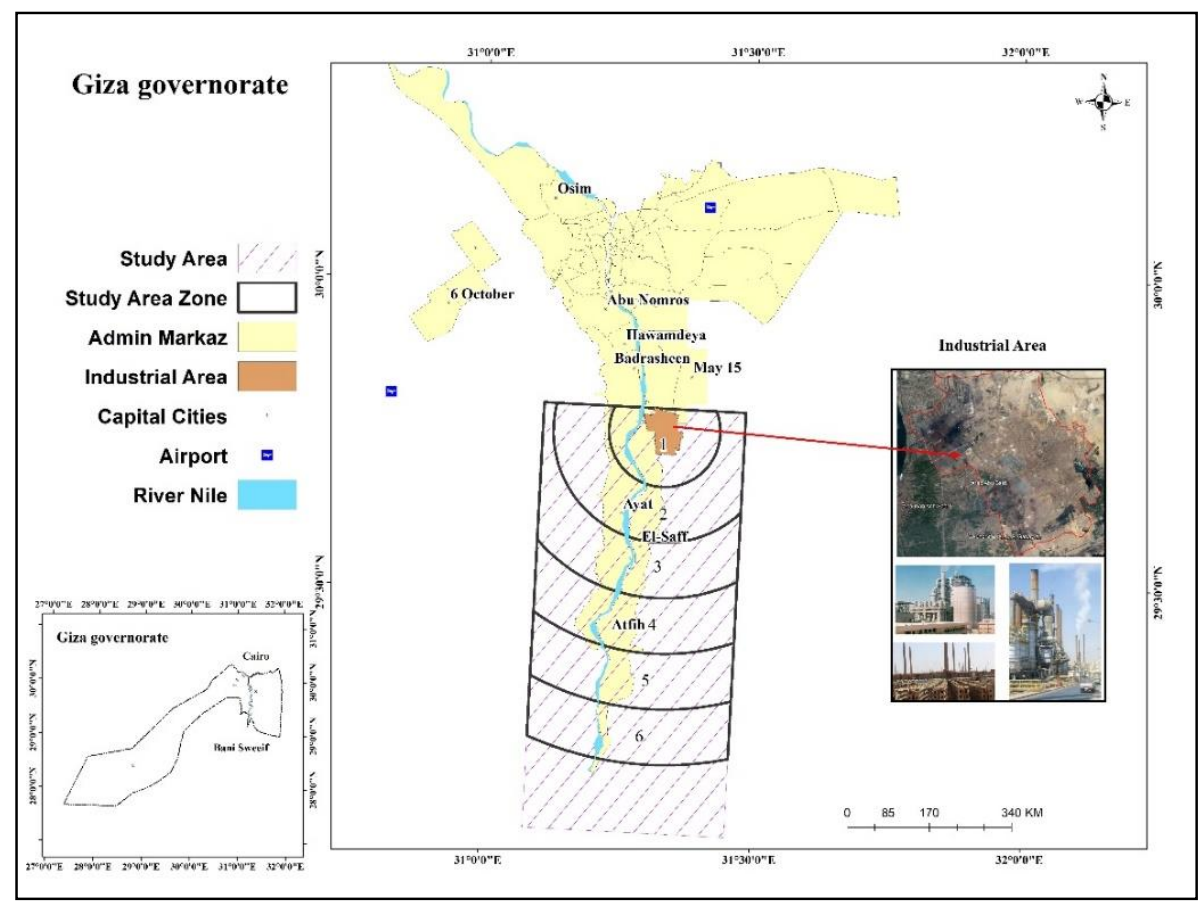

Fig. 1. The Study Area Location

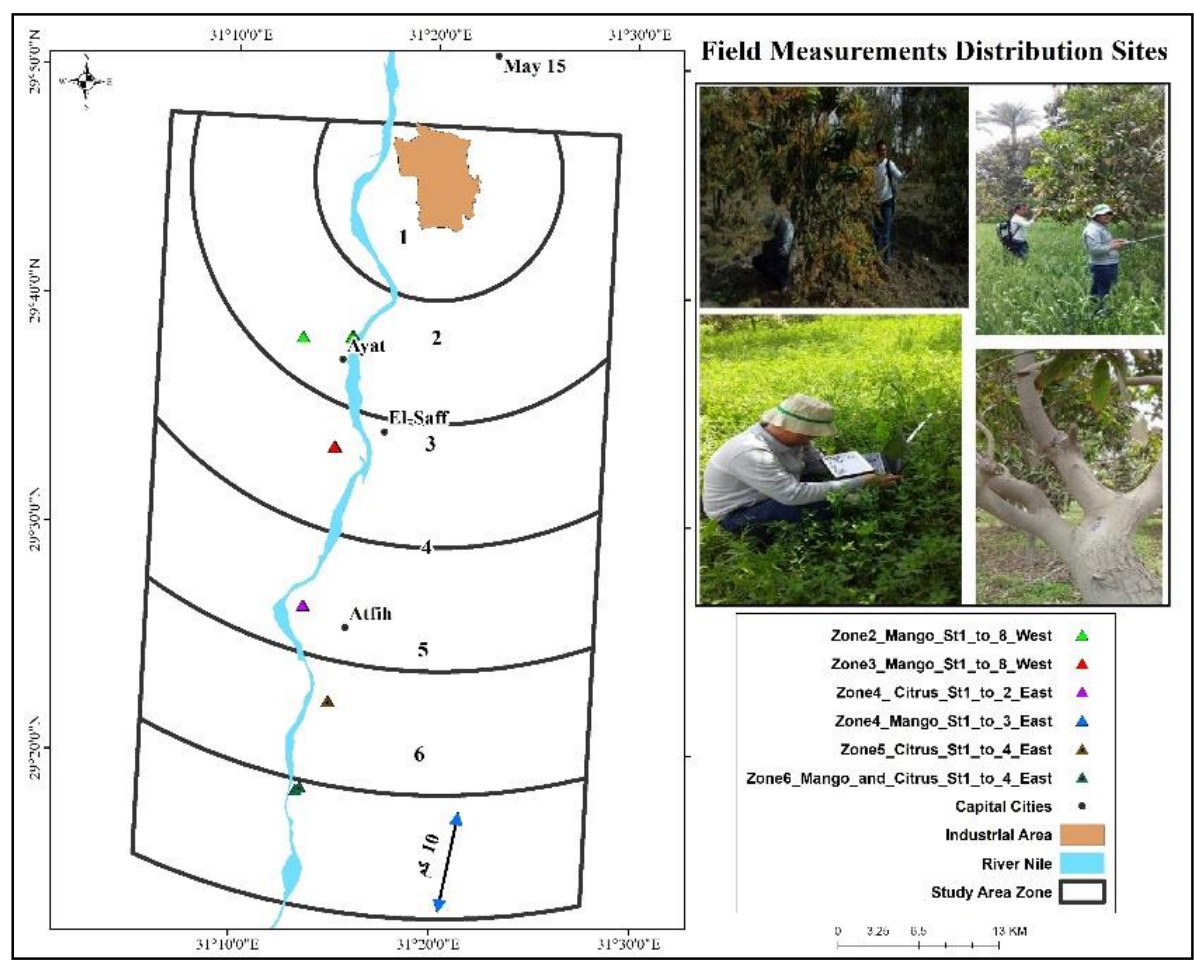

Fig. 2. Location map for plant samples 


\subsubsection{Vegetation Indices}

Hyper-spectral indices were computed from Algebraic ratios of different types around red $(R)$ and near-infrared bands: (NIR) Normalized Vegetation Difference Index (NDVI) (Rouse et al 1973) and Soil Adjusted Vegetation Index (SAVI), which were calculated as follows:

$N D V I=\left(R_{800}-R_{670}\right) /\left(R_{800}-R_{670}\right) \quad \ldots .$. Equation (1)

Where: pr and pNIR respectively are spectral reflections of $R$ and NIR bands.

$S A V I=(1+L)\left(R_{800}-R_{670}\right) /\left(R_{800}-R_{670}+L\right) \quad \ldots$. Equation (2)

Where: (pr) and (pNIR) spectral reflection from the spectro-scopic measurements, including both of $(R)$ and (NIR) band, and (L) is an ideal adjustment factor. (Huete, 1988) defined the ideal adaptive algorithm $L=(0.25),(0.5)$, or (1.0) to be considered for medium, moderate or low field vegetation density, respectively. He hinted at (SAVI) $L=(0.5)$. According to NDVI, the effect of soil differences in green vegetation is effectively minimized.

\section{Model calibration and validation}

Randomly selected $70 \%$ of the collected samples were used for modeling while $30 \%$ were used for validation for spectroscopic and laboratory measurements. The process of spectral modeling was performed using a simple linear regression model and the models (one for each plant parameter) were calibrated using the coefficient of determination $\left(R^{2}\right)$, and root means square error (RMSE).

\section{RESULTS AND DISCUSSION}

Different simple regression mathematical models were generated using contamination of heavy metals as a variable dependent and each of, red spectral band, NIR spectral band, and two vegetation indices (NDVI and SAVI) as independent ones. Table (1) shows the generated models to estimate heavy metals contamination using remote sensing factors for Mango samples and the correlation coefficient $\left(R^{2}\right)$ for each generated model.
Table 1. Simple regression models for heavy metals and spectral data for Mango samples

\begin{tabular}{|c|c|c|c|}
\hline Elements & $\begin{array}{c}\text { Spectral } \\
\text { band }\end{array}$ & $\mathbf{R}^{2}$ & Simple regression Model \\
\hline \multirow{4}{*}{$\mathbf{P b}$} & $\mathrm{R}$ & 0.836 & $-8.449+377.010^{*} R$ \\
\hline & IR & 0.943 & $-251.465+561.638^{*} \mid R$ \\
\hline & NDVI & 0.92 & $-57.310+110.193^{*}$ NDVIA \\
\hline & SAVI & 0.903 & $-70.271+157.756 *$ SAVI \\
\hline \multirow{4}{*}{$\mathrm{Cr}$} & $\mathrm{R}$ & 0.87 & $3.587+144.68^{\star} R$ \\
\hline & IR & 0.94 & $-88.973+210.084^{*} \mathrm{NIR}$ \\
\hline & NDVI & 0.875 & $-14.904+41.947^{\star} \mathrm{NDVI}$ \\
\hline & SAVI & 0.88 & $-18.759+58.299 *$ SAVI \\
\hline \multirow{4}{*}{ Cd } & $R$ & 0.892 & $-21.487+620.669^{*} R$ \\
\hline & IR & 0.9 & $-399.414+879.5^{\star} I R$ \\
\hline & NDVI & 0.716 & $-86.773+161.595^{\star} \mathrm{NDVI}$ \\
\hline & SAVI & 0.754 & $-104.832+229.79 *$ SAVI \\
\hline \multirow{4}{*}{ ZN } & $R$ & 0.96 & $-15.733+406.025^{\star} R$ \\
\hline & IR & 0.942 & $-256.715+563^{\star} I R$ \\
\hline & NDVI & 0.711 & $-55.089+101.285^{\star} \mathrm{NDVI}$ \\
\hline & SAVI & 0.751 & $-66.530+144.23 \mathrm{SAVI}$ \\
\hline \multirow{4}{*}{$\mathrm{Ni}$} & $R$ & 0.931 & $-16.377+518.999^{*} R$ \\
\hline & IR & 0.947 & $-331.703+734.374^{*} \mid R$ \\
\hline & NDVI & 0.719 & $-68.996+132.496 * \mathrm{NDVI}$ \\
\hline & SAVI & 0.77 & $-85.101+190.534^{\star}$ SAVI \\
\hline \multirow{4}{*}{$\mathrm{Hg}$} & $R$ & 0.957 & $-45.512+1134.572^{*} R$ \\
\hline & IR & 0.976 & $-726.176+1587.91^{*} \mid R$ \\
\hline & NDVI & 0.75 & $-162.286+291.936 * N D V I$ \\
\hline & SAVI & 0.781 & $-193.27+412.503^{\star}$ SAVI \\
\hline
\end{tabular}

There is a distinctive relationship between heavy metal contaminations like with (red) and (NIR) band, (NDVI) and (SAVI) according to regression equations. These models were validated using two statistical analyzes involving regression analysis between actual and expected contamination. For each model, $\left(R^{2}\right)$ values as well as the RMSE are presented in Table (2). The models are found to be sufficient for forecasting heavy metals as they recorded higher than (0.8) of $R^{2}$. Such analysis almost agreed with the result of the analysis of the RMSE except for $\mathrm{Hg}$ that showed relatively high RMSE of (12.2) with NDVI and (11.2) with SAVI models as shown in Table (2). 


\section{Assessment of Spectroscopic and Morphological Properties of some Fruit Crops under the Influence of Pollution with Heavy Metals Using Remote Sensing Techniques}

Table 2. Coefficient determined by $\left(R^{2}\right)$ and Root Mean Square Error (RMSE) of real and expected heavy metals of various spectral bands obtained from ASD spectroradiometers and Mango vegetation indices.

\begin{tabular}{|c|c|c|c|}
\hline Elements & $\mathbf{R}$ & $\mathbf{R}^{2}$ & RMSE \\
\hline \multirow{4}{*}{$\mathrm{Pb}$} & $\mathrm{R}$ & 0.85 & 2.9 \\
\hline & IR & 0.99 & 1.8 \\
\hline & NDVI & 0.834 & 3.6 \\
\hline & SAVI & 0.916 & 2.7 \\
\hline \multirow{4}{*}{$\mathrm{Cr}$} & $\mathrm{R}$ & 0.86 & 1.1 \\
\hline & IR & 0.94 & 0.79 \\
\hline & NDVI & 0.876 & 1.19 \\
\hline & SAVI & 0.88 & 1.16 \\
\hline \multirow{4}{*}{ Cd } & $\mathrm{R}$ & 0.934 & 3.3 \\
\hline & IR & 0.919 & 3.9 \\
\hline & NDVI & 0.688 & 7.4 \\
\hline & SAVI & 0.742 & 6.9 \\
\hline \multirow{4}{*}{$\mathrm{Zn}$} & $\mathrm{R}$ & 0.96 & 1.5 \\
\hline & IR & 0.943 & 2.1 \\
\hline & NDVI & 0.699 & 4.5 \\
\hline & SAVI & 0.755 & 4.2 \\
\hline \multirow{4}{*}{ NI } & $\mathrm{R}$ & 0.953 & 2.3 \\
\hline & IR & 0.950 & 2.5 \\
\hline & NDVI & 0.71 & 5.9 \\
\hline & SAVI & 0.77 & 5.3 \\
\hline \multirow{4}{*}{$\mathrm{Hg}$} & $\mathrm{R}$ & 0.962 & 4.6 \\
\hline & IR & 0.95 & 5.5 \\
\hline & NDVI & 0.738 & 12.2 \\
\hline & SAVI & 0.77 & 11.2 \\
\hline
\end{tabular}

For Citrus samples, the generated models to estimate contamination of heavy metals for Citrus samples, and the correlation coefficient for each model are shown in Table (3). It was found that there is a distinct correlation between contamination of heavy metals with red band, NIR band, NDVI, and SAVI. The generated model to estimate $\mathrm{Pb}$ element showed relatively high accuracy with Red model and NIR model with $\left(R^{2}\right) 0.83$ and 0.82 . At the same time, NDVI and SAVI based models showed relatively low $R^{2}(0.43)$ and $(0.58)$. Almost the same trend was found with $\mathrm{Cr}, \mathrm{Cd}, \mathrm{Zn}$ and $\mathrm{Hg}$ when $\mathrm{Ni}$ element showed relatively low accuracy for red model.

These models were validated using two statistical analyzes including regression analysis between real and expected performance for each model and $R^{2}$ values, as well as the RMSE as shown in Table (4). It is observed that Models were adequate for heavy metal prediction as they recorded higher than 0.8 of $R^{2}$ for each element and model. Such analysis was almost agreed with the results of the RMSE analysis except for $\mathrm{Cd}$ that showed Higher RMSE for 5.4 NDVI models as shown in Table (4).

Table 3. Simple regression models for heavy metals and spectral data for Citrus

\begin{tabular}{|c|c|c|c|}
\hline Elements & $\begin{array}{l}\text { Spectral } \\
\text { band }\end{array}$ & $\mathbf{R}^{2}$ & $\begin{array}{c}\text { Simple regression } \\
\text { Model }\end{array}$ \\
\hline \multirow{4}{*}{$\mathrm{Pb}$} & $R$ & 0.835 & $6.602+233.88^{*} R$ \\
\hline & IR & 0.821 & $-115.32+269.3 I R$ \\
\hline & NDVI & 0.43 & $-22.808+58.399 \mathrm{NDVI}$ \\
\hline & SAVI & 0.58 & $-32.450+86.329^{*} \mathrm{SAVI}$ \\
\hline \multirow{4}{*}{$\mathrm{Cr}$} & $\mathrm{R}$ & 0.78 & $6.707+133.062^{*} \mathrm{R}$ \\
\hline & IR & 0.757 & $-61.793+151.560 * \mid R$ \\
\hline & NDVI & 0.34 & $-7.788+30.499 * \mathrm{NDVI}$ \\
\hline & SAVI & 0.49 & $-13.853+46.62 *$ SAVI \\
\hline \multirow{4}{*}{ Cd } & $R$ & 0.67 & $-1.675+588.26^{*} R$ \\
\hline & IR & 0.89 & $-364.419+784.9 * \mid R$ \\
\hline & NDVI & 0.656 & $-124.694+206.619 * \mathrm{NDVI}$ \\
\hline & SAVI & 0.74 & $-137.655+273.74^{*}$ SAVI \\
\hline \multirow{4}{*}{ ZN } & $\mathrm{R}$ & 0.83 & $-5.010+319.093^{*} R$ \\
\hline & IR & 0.88 & $179.07+382.228^{*} \mid R$ \\
\hline & NDVI & 0.4 & $-43.346+77.497^{*} \mathrm{NDVI}$ \\
\hline & SAVI & 0.56 & $-57.326+116.336 *$ SAVI \\
\hline \multirow{4}{*}{$\mathbf{N i}$} & $R$ & 0.569 & $17.589+210.624^{\star} R$ \\
\hline & IR & 0.835 & $-120.206+296.209 * \mid R$ \\
\hline & NDVI & 0.68 & $-31.169+79.717^{\star} \mathrm{NDVI}$ \\
\hline & SAVI & 0.767 & $-37.927+108.244^{*}$ SAVI \\
\hline \multirow{4}{*}{$\mathrm{Hg}$} & $R$ & 0.705 & $10.392+468.7^{\star} R$ \\
\hline & IR & 0.908 & $-274.448+617.37^{\star} I R$ \\
\hline & NDVI & 0.55 & $-70.628+143.929 * N D V I$ \\
\hline & SAVI & 0.65 & $-86.145+200.4^{*} \mathrm{SAVI}$ \\
\hline
\end{tabular}


Table 4. Coefficient of determination $\left(R^{2}\right)$ and Root Mean Square Error (RMSE) of actual and predicted heavy metals of various spectral bands obtained for Citrus from the ASD spectroradiometer and vegetation indices.

\begin{tabular}{|c|c|c|c|}
\hline Elements & $\bar{R}$ & $\mathbf{R}^{2}$ & RMSE \\
\hline \multirow{4}{*}{$\mathrm{Pb}$} & $R$ & 0.8 & 2.55 \\
\hline & IR & 0.8 & 2.11 \\
\hline & NDVI & 0.4 & 2.12 \\
\hline & SAVI & 0.7 & 1.7 \\
\hline \multirow{4}{*}{$\mathrm{Cr}$} & $\mathrm{R}$ & 0.7 & 1.5 \\
\hline & IR & 0.8 & 1.2 \\
\hline & NDVI & 0.4 & 1.1 \\
\hline & SAVI & 0.6 & 1.05 \\
\hline \multirow{4}{*}{ Cd } & $\mathrm{R}$ & 0.8 & 6.5 \\
\hline & IR & 0.9 & 4.7 \\
\hline & NDVI & 0.7 & 5.2 \\
\hline & SAVI & 0.8 & 3.5 \\
\hline \multirow{4}{*}{$\mathrm{Zn}$} & $\mathrm{R}$ & 0.8 & 2.8 \\
\hline & IR & 0.9 & 1.7 \\
\hline & NDVI & 0.5 & 2.7 \\
\hline & SAVI & 0.7 & 2.15 \\
\hline \multirow{4}{*}{ NI } & $\mathrm{R}$ & 0.8 & 2.3 \\
\hline & IR & 0.8 & 2.5 \\
\hline & NDVI & 0.7 & 2.06 \\
\hline & SAVI & 0.8 & 1.5 \\
\hline \multirow{4}{*}{$\mathrm{Hg}$} & $R$ & 0.7 & 5.6 \\
\hline & IR & 0.9 & 3.09 \\
\hline & NDVI & 0.6 & 4.3 \\
\hline & SAVI & 0.8 & 3.1 \\
\hline
\end{tabular}

\section{CONCLUSION}

In the current study, statistical models were generated to estimate heavy metal contamination of Mango and Citrus leaf samples. The developed models used remote sensing factors as estimators in the form of spectral reflectance or vegetation indices. The validation analysis could be concluded for the generated models; using spectral bands (NIR and Red) and VIs (NDVI and SAVI) are adequate to predict the accumulation of heavy metals in Mango. Red and NIR showed higher accuracy to predict citrus heavy metals more than VIs for $\mathrm{Pb}, \mathrm{Cr}$, $\mathrm{Cd}, \mathrm{Zn}$, and $\mathrm{Hg}$ Under normal ambient and common agricultural practices. ASD spectroradiometer technique can be a useful method to determine the heavy metals content of citrus and mango. All models produced are empirical models limited to the environment and applicable under similar conditions.

\section{REFERENCES}

Asati A. and Pichhode M. and Nikhil K. 2016. Effect of Heavy Metals on Plants: An Overview. Int. J. of Application or Innovation in Engineering \& Management 5(3), 2319-4847.

Baiano A., Terracone C., Peri G. and Romaniello R. 2012. Application of hyperspectral imaging for prediction of physico-chemical and sensory characteristics of table grapes. Comput. Electron. Agric. 87, 142-151.

Bhatti A.U. and Perveen S. 2005. Heavy metals hazards in agriculture in NWFP. Proceedings of the First International Conference on Environmentally Sustainable Development. Department of Environmental Sci., COMSATS Inst. Info. Tech. Abbottabad, Pakistan. pp. 1513-1518.

Bonifazi G., Menesatti P. and Millozza M. 2004. Multiand hyperspectral digital imaging based techniques for agricultural soil characterization, in Proceedings of the International Society for Optical Engineering "Nondestructive Sensing for Food Safety, Quality, and Natural Resources (International Society for Optical Engineering, Bellingham, WA, and Vol. 5587, pp. 1-9.

EIMasry G., Wang N., ElSayed A. and Ngadi M. 2007. Hyperspectral imaging for nondestructive determination of some quality attributes for strawberry. J. Food Eng. 81, 98-107.

Fan S., Huang W., Guo Z., Zhang B. and Zhao C. 2015. Prediction of soluble solids content and firmness of pears using hyperspectral reflectance imaging. Food Anal. Methods 8, 19361946.

Hu M.H., Dong Q.L., Liu B.L., Opara U.L. and Chen L. 2015. Estimating blueberry mechanical properties based on random frog selected hyperspectral data. Postharvest Biol. Technol. 106, 1-10.

Huete A.R. 1988. A soil vegetation adjusted index (SAVI). Remote Sens. Environ, 25, 295-309.

Leiva-Valenzuela Lu, R. and Aguilera J.M. 2013. Prediction of firmness and soluble solids content of blueberries using hyperspectral reflectance imaging. J. Food Eng. 115, 91-98.

Lu R. 2004. Multispectral imaging for predicting firmness and soluble solids content of apple fruit. Postharvest Biol. Technol. 31, 147-157.

Mendoza F., Lu R., Ariana D., Cen H. and Bailey B. 2011. Integrated spectral and image analysis of hyperspectral scattering data for prediction of 


\section{Assessment of Spectroscopic and Morphological Properties of some Fruit Crops under the Influence of Pollution with Heavy Metals Using Remote Sensing Techniques}

apple fruit firmness and soluble solids content. Postharvest Biol. Technol. 62, 149-160.

Misra S.G. and Mani D. 1991. Heavy metals pollutant in: Soil Pollution. Ashish Publishing House, New Delhi, 60 p.

Mohamed E.S., Ali A.M., El Shirbeny M.A., Afaf A. Abd El Razek and Yu Savin I. 2016. Near Infrared Spectroscopy Techniques for Soil Contamination Assessment in the Nile Delta." Eurasian Soil Sci., 49(6), 632-39.

Monni S., Salemma M. and Millar N. 2000. The tolerance of Empetrum nigrum to copper and nickel. Environ Pollut 109, 221-229.

Mussarat M. and Bhatti A.U. 2005. Heavy metal contents in fodder crops growing in the vicinity of Peshawar City. Soil and Environ, 24(1), 5862.
Qadir M.A., Mitra A., Gupta S.K. and Murtaza G. 1999. Irrigation with city effluents for growing vegetables: A silent epidemic of metal poisoning. Proceeding of Pakistan Academy of Sci., 36, 217-222.

Reeves R.D. and Baker A.J.M. 2000. Metal-accumulating plants. In: Raskin I, Ensley BD (eds.) Phytoremediation of toxic metals: using plants to clean up the environment. Wiley, New York, USA, pp. 193-229.

Rouse J.W., Haas R.H., Schell J.A., Deering D.W. and Harlan J.C. 1974. Monitoring the vernal advancements and retrogradation of natural Vegetation. In: NASA/GSFC, Final Report, Green belt, MD, USA pp. 1-137.

Wintz H., Fox T. and Vulpe C. 2002. Responses of plants to iron, zinc and copper deficiencies. Biochem Soc. Trans 30, 766-768. 


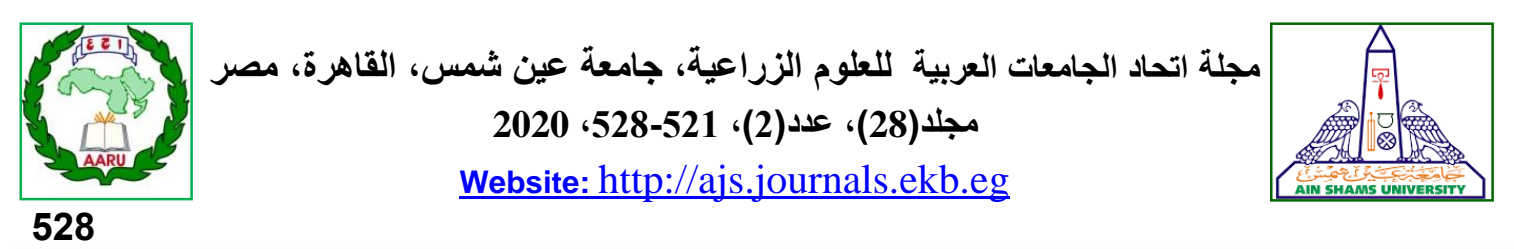

تتبع الخصائص الإسبكتروسكوبية والمورفولوجية لبعض محاصيل الفاكهة

تحت تأثير التلوث بالعناصر الثقيلة بإستخدام الإستثعار من البعد

$$
\begin{aligned}
& \text { أمانى فاروق الوسيمى1" - نظمى عبدالحميد عبدالغنى2 - - أيمن فريد أبوحديد2 - مدئ } \\
& \text { محمد أمين إبراهيم أبوالغار } 1 \\
& \text { 1- الهيئة القومية للأستثعار من البعد وعلوم الفضاء - النزهة الجديدة - القاهرة - مصر إلفرار } \\
& \text { 2- قسم البساتين- كلية الزراعة - جامعة عين شمس - صندوق بريد } 68 \text { - حدائق شبرا } 11241 \text { - القاهرة - مصر }
\end{aligned}
$$

*Corresponding author: amanysearch@ gmail.com

Received 3 May, 2020

Accepted 24 August, 2020

المستخرجة من القياسات الحقلية والقياسات التحليلية

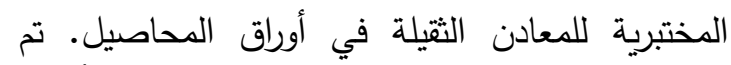

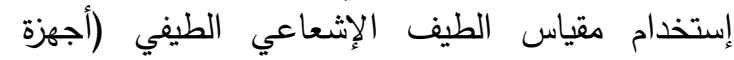
التحليل الطيفي) لحساب مؤشرات الغطاء النيفي النباتي

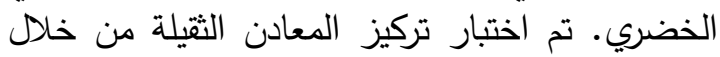

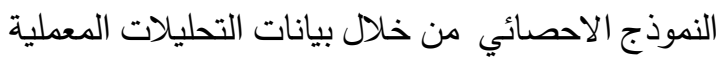

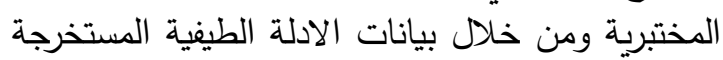

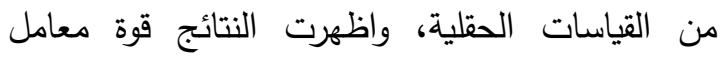
الارتباط، ومن خلال النطاقات الطيفية الحمراء وشبة وات التهاء تحت الحمراء كانت الدقة عالية وكافية فى التتبؤ بتركيز

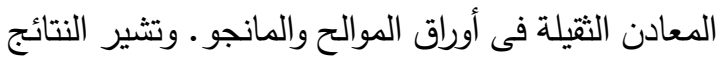
بشكل عام ان إستخدام المؤشرات النباتية للبيانات الطيفية الطئية

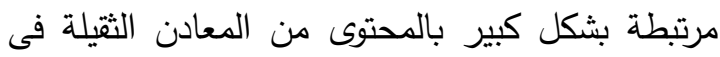

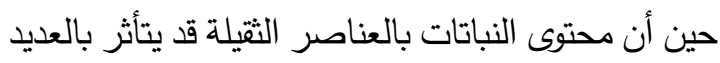

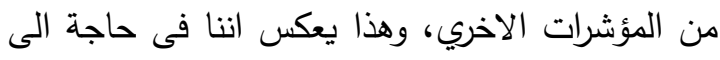

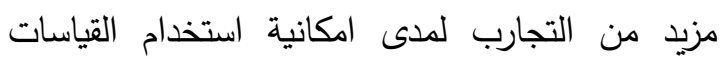

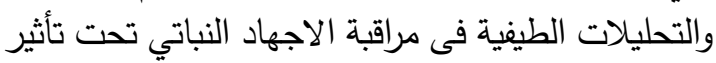

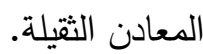

الكلمات المفتاحية: المعادن الثقيلة، المؤشرات النباتية

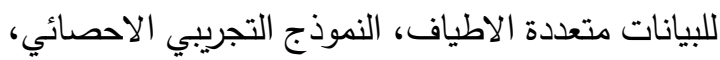

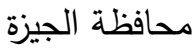

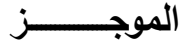

يشكل التلوث بالمعادن الثقيلة (الرصاص - الكروم

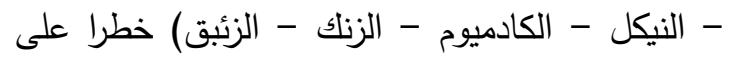

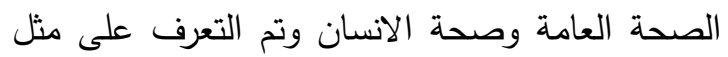
هذه العناصر من خلال الاستهلاك للخضروات والدان والفواكة

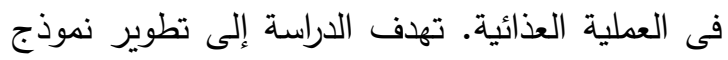

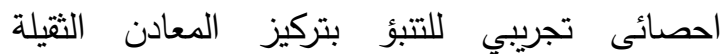

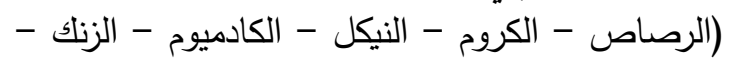

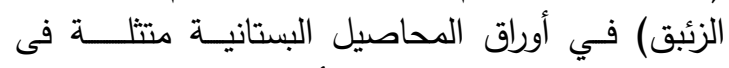

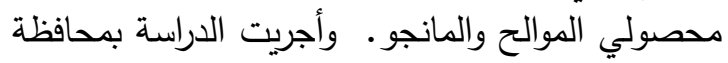

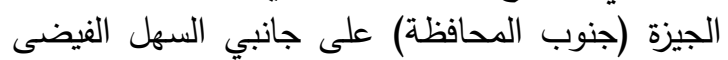

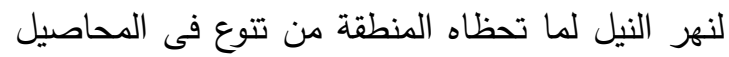

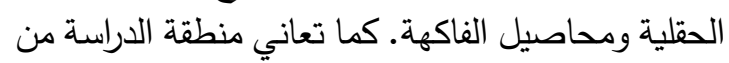

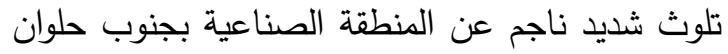

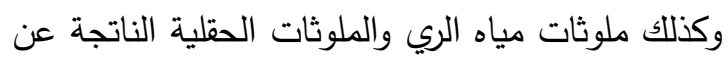
عمليات التسميد. وتم تقسيم المنطقة الى ستة نطات الطاقات

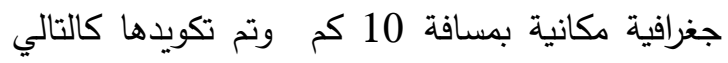

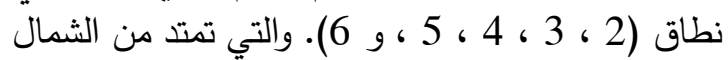
إلى الجنوب وتغطي 60٪ 3ن من مساحة الاراضى الزراعية

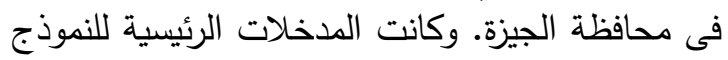
الاحصائي المستخدم فى الدراسة هي البيانات الطيفية 